Historic, Archive Document

Do not assume content reflects current scientific knowledge, policies, or practices. 



\section{HARDY HERBACEOUS PLANTS}

For

BORDER AND ROCK GARDEN

\section{NEW THINGS THIS YEAR}

This list is printed as a supplement to my list of last year. Herein you will find a record of the new species and varieties added to my nursery since the spring of 1928. Most of these are choice and rare rock garden plants.

In addition to these $I$ am growing other new things from seed. From the Alps, the Rocky Mountains, the Pacific Northwest, England and New England are coming seeds or plants to my collection. There is something new every time you come out.

Last summer was a good growing season. I have larger stocks of many items than ever before. The weather fates have been good this past winter.

As spring opens, I'll be on hand each evening from four on to darkness, and all day Saturday to greet you. Whether you are in need of plants or just want to browse around and gossip, you are welcome.

Drive north of Worthington on High Street one mile to Wilson Road, turn west 1000 feet and my place is the second house on the north side, a colonial brick. Drive in and if I'm not in sight, look for the old dinner bell.

"If the gardener you fail to see-

Ring the bell right lustilee."

HARRY R. O'BRIEN

\section{FOUR O'CLOCK GARDEN NURSERY}

"Come After Four, Please"

WILSON ROAD, WEST

WORTHINGTON, OHIO 


\section{HARDY HERBACEOUS PERENNIAL PLANTS \\ SUPPLEMENTARY PRICE LIST}

AETHIONEMA (Lebanon Candytuft).

Each Doz.

Persicum. An almost shrubby little rock plant with bluish foliage and pink blossoms resembling candytuft

AJUGA (Bugle Weed).

This is a good rock garden plant for the beginner, especially

if there is a large space to be covered. These grow rapidly and thrive in shade.

Reptans rubra. Forms close carpet, 2-4 inches

Metallica crispa. Crinkled foliage, blue flowers

ALYSSUM (Perennial Sweet Alyssum).

Saxatile Var. citrinum. From Correvon seed. Paler yellow than type

ANDROSACE (Rock Jasmine).

Lanuginosa Leichtlini. Most alpine of alpines

Primuloides. Similar to sarmentosa

Sarmentosa. Coming from the Himalayas, this is a jewel for a rock garden. Pink flowers on six inch stems in June that resemble verbenas

AQUILEGIA (Columbine).

Caerulea (Rocky Mountain Columbine). Blue and white. I have several types including some from Colorado mountain seed

ARENARIA (Sandwort).

Balearica (Corsican sandwort)

Caespitosa. Close tufted, with white flowers all summer -..

Montana. White flowers, early, creeping. One of the best rock plants

ARMERIA (Sea Pink or Thrift).

Maritima. Pink, May-June, 6 inches

ARTEMISIA.

Frigida. An odd plant for the rock garden

ASTER, PERENNIAL.

Alpinus rubra. Rose, 10 inches, May, for rock garden

Apricus. New rare summer-flowering aster from the Rocky Mountains with large lavender-violet rays

AUBRETIA (Rock Cress).

Large Flowering Hybrids

CAMPANULA (Bell Flower).

Garganica. One of the choicest for rock garden. Trailing rosettes, light blue flower with white eye

Laurii. New species from Greek Islands. Large, beautiful lavender flowers that turn up instead of drooping. A rock garden jewel, 10 inches

Petiolata. This is the Colorado harebell, often listed as

C. rotundifolia. It is a long blooming, valuable rock plant

CHELONE (Turtlehead).

Lyoni. Purplish red flowers

DIANTHUS (Pinks).

Arenarius. Sand pink

Barbatus. (Sweet William). I have excellent plants of Vaughan's Special Mixture and of single and double black and double blood red.

Special price for spring only

Deltoides albus. White form of maiden pink

Latifolius atrococcineum f. pl. Double Sweet William. Brilliant scarlet.

RICA (Heath).

Stricta. (Corsican heath). A dwarf, bushy shrub, suitable for rockery. Pink flowers 
These listed are all hardy natives, suitable for the rock garden. They like shade.

Adiantum pedatum (Maidenhair fern)

Asplenium ebeneum (Ebony spleenwort)

Polypodium vulgare (Common polypody)

Woodsia ilvensis (Rusty woodsia)

Woodsia obtusa (Obtuse-leaved woodsia)

GEUM.

Ciliatum (Western rosy avens). A rock garden gem of spring bloom from the Rockies

GYPSOPHILA (Baby's Breath).

Repens. A dwarf, trailing plant with white flowers in midsummer, for rock garden

HELIANTHEMUM (Rock Rose).

Buttercup. Yellow

Fireball. Scarlet, double

HELENIUM (Sneezewort).

Hoopesii. A beautiful, rare helenium from the Rockies, 18 inches, with large yellow flowers

IRIS GERMANICA.

8.0 Cluny. Lilac-blue

\section{LEONTOPODIUM (Edelweiss).}

Alpinum. A romantic, famous rock plant

\section{LEWISIA.}

Rediviva (Bitterroot). This is the state flower of Montana. A good rock plant from the west

LIATRIS.

Ligulistylis (Rocky Mountain Gayfeather). A dwarf, early species with showy heads of rosy purple. A gift from the Rockies to our rock gardens

LILIUM.

Candidum. Madonna lily

Tenuifolium. Dwarf, 18 inches, scarlet flowers and blooming in early June. A treasure for the rock garden

LYSIMACHIA (Loosestrife).

Clethroides. White, 2 feet, midsummer on

MATRICARIA (Feverfew).

Golden Ball. Dwarf, with tiny deep yellow balls of bloom. Most attractive

MYOSOTIS (Forget-me-not).

Alpestris. Blue

Alpestris rosea

Palustris semperflorens. Blue

Palustris semperflorens "Pink Beauty"

NEPETA (Catmint).

Nuda. A new, rare variety from Switzerland

PENTSTEMON.

Barbatus "Pink Beauty"

Humilis (Blue-Hill pentstemon). A dwarf form with blue flowers from the Colorado mountains for rock gardens -.-

\section{PHLOX.}

Amoena. A sheet of bright pink in early spring, 4 inches. More neat than subulata. One of best plants for rock garden

Subulata alba. Pure white

Subulata "Fairy". New. Resembles "Vivid" in habit but with pale blue flower and purple eye.

Subulata lilacina. Light lilac 
PLATYCODON (Balloon Flower).

Mariesi. Dwarf, compact, 12 inches, blue

POTENTILIA (Cinquefoil).

Nepalensis "Miss Willmott". Dwarf, cherry red …__. .25

SAXIFRAGA.

These are all admirable plants for rock garden.

Crassifolia. Pink, April to June

Decipiens. Mossy, 4 inches, pink and white

Macnabiana. Encrusted. Rare

Michauxi. Rare native

SEDUM.

Aizoon. Yellow flowers, midsummer, 12 inches

Dasyphyllum. As dainty as a jewel or fine lace

Ewersi. Attractive and rare ___ $\quad .50$

Pruniatum Fosterianum. Rare ________________- $\quad .35$

Pulchellum. True variety _-___

Reflexum

Stahlii. - Dwarf

SEMPERVIVUM (Houseleek).

These are suitable for rock garden.

Arachnoideum. Cobweb houseleek

Calcarem. Rare, lime-encrusted from Alps _._.

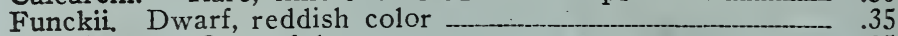

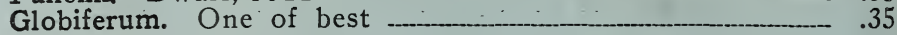

SYNTHYRIS.

Plantaginea (Kittentails). An attractive rock plant with silky spikes of bluish flowers from the Rocky Mountains -

THYMUS (Thyme).

Thymes are admirable rock garden plants.

Lanuginosus. Wooly leaved thyme

Serpyllum. Seedlings, from Correvon seed - _ -

Serypllum coccineum. Crimson flowers

TIARELLA (False Miterwort).

Cordifolia. For shady rock garden

TUNICA (Coat Flower).

Saxifraga. Prostrate rockery plant with rose flowers

VALERIANA.

Acutiloba. A dwarf alpine from the Rocky Mountains. White flowers in spring

VERONICA (Speedwell).

Multifida. Rare rock plant from Asia Minor _.__ $\quad .75$

Spurium "Royal Blue" (Amethystina) ____________ .35

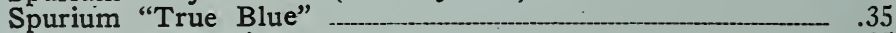

Teucrium rupestris nana

YUCCA.

Coloma (Soapwort). A dwarf yucca from Colorado suitable for a small rock garden. It likes plenty of moisture. A gem

Member-Ohio Nurserymen's Association

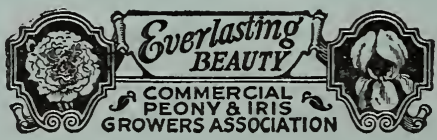

